\title{
The Role of Petals in Development of Grey Mould in Strawberries
}

\author{
Pedro Boff ${ }^{1}$, Joop de Kraker ${ }^{2}$, Mathijs Gerlagh ${ }^{3}$ \& Jürgen Köhl ${ }^{3}$
}

${ }^{1}$ Estação Experimental de Ituporanga, Empresa de Pesquisa Agropecuária e Extensão Rural de Santa Catarina-EPAGRI, Cx. Postal 121, 88400-000 Ituporanga, SC, Brasil, fax: (++51)(47)5331364, e-mail: pboff@epagri.rct-sc.br; ${ }^{2}$ Department of Plant Sciences, Wageningen University, P.O. Box 430, 6700 AK Wageningen, The Netherlands; ${ }^{3}$ Plant Research International B.V., P.O. Box 16, 6700 AA Wageningen, the Netherlands, e-mail: j.kohl@ plant.wag-ur.nl

(Accepted for publication on 07/11/2002)

Corresponding authors: Pedro Boff and Jürgen Köhl

BOFF, P., DE KRAKER, J., GERLAGH, M. \& KÖHL, J. The role of petals in development of grey mould in strawberries. Fitopatologia Brasileira 28:076-083. 2003.

\begin{abstract}
Studies were conducted in annual crops of strawberry (Fragaria $\mathrm{x}$ ananassa) (cv. Elsanta to assess the relative importance of petals as an inoculum source of grey mould, caused by Botrytis cinerea and to identify during which period of flower and fruit development the presence of petals has a significant effect on development of grey mould on fruits. In 1998, the incidence of B. cinerea on flower parts was assessed, and the symptoms of grey mould on fruits were characterised with regards to their starting point. The incidence of $B$. cinerea on petals was $65-85 \%$ of those flowers that harboured $B$. cinerea. The starting point of symptoms was located underneath the sepals in $65-85 \%$ of fruits with grey mould, and petals were present at this site in about $50 \%$ of the cases. In 1999, four field experiments were conducted to assess the effect of petal removal at different stages of flower and fruit development on

incidence of grey mould. The incidence of grey mould on fruits with petals retained till harvest was circa $55 \%$ more than on fruits where petals were removed or had dropped naturally by the end of flowering, regardless of planting date or inoculum level of $B$. cinerea. The incidence of grey mould was hardly different between treatments where petals were removed at young flower stage, old flower stage, or green fruit stage. It is concluded that petals are an effective and stable source of inoculum for fruit infection by $B$. cinerea. Considering the high probability that retention of petals during fruit expansion and ripening results in fruit infection, the elimination of petals as an inoculum source appears worthwhile even when the incidence of petal retention on fruits is relatively low.

Additional key words: strawberries, Botrytis cinerea, flower, epidemiology, inoculum source, phenology.

\section{RESUMO}

Importância das pétalas no desenvolvimento do mofo-cinzento do morangueiro

Neste trabalho objetivou-se estudar a importância de partes florais, especialmente pétalas, como fonte de inóculo no desenvolvimento do mofo-cinzento dos frutos do morangueiro (Fragaria x ananassa), causado por Botrytis cinerea, e identificar os estágios de floração e frutificação nos quais a presença de pétalas pode influir no aumento da doença. Preliminarmente, em 1998, foi avaliada a distribuição espacial de $B$. cinerea nas flores e caracterizou-se o tipo de sintoma inicial do mofo-cinzento nos frutos. Em pétalas, o patógeno esteve presente em 65 a $85 \%$ das flores. Estames foram colonizados em 85 a $100 \%$ dos casos. Sintomas iniciais do mofo-cinzento estiveram localizados sob as sépalas em 65 a $85 \%$ dos casos, dos quais $50 \%$ apresentaram presença de pétalas. Em 1999, conduziram-se quatro experimentos para estudar

o efeito da remoção de pétalas na incidência do mofo-cinzento nos frutos. A incidência do mofo-cinzento em frutos, média dos quatro experimentos, com uma ou mais pétalas presentes até a colheita foi em torno de $55 \%$ a mais do que nos frutos onde pétalas foram removidas ou caíram naturalmente no final da floração. Não houve diferença na incidência do mofo-cinzento entre os tratamentos com remoção de pétalas até no estágio de flor-jovem, flor-velha e frutoverde. Conclui-se que pétalas podem constituir-se numa fonte efetiva e estável de inóculo de $B$. cinerea, capaz de causar infecção nos frutos. Considerando uma alta probabilidade de permanência de pétalas durante o estágio expansão e amadurecimento de frutos, a remoção e/ou neutralização dessas pétalas como fonte de inóculo, pode contribuir substancialmente na redução do mofo-cinzento do morangueiro, mesmo que a percentagem de retenção de pétalas nos frutos até a colheita for baixa.
\end{abstract}

\section{INTRODUCTION}

Grey mould, caused by Botrytis cinerea Pers. Ex. Fr. [teleomorph: Botryotinia fuckeliana (de Bary) Whetzel], is

Part of PhD thesis of the first author developed at Plant Research International B.V., P.O. Box 16, 6700 AA Wageningen, the Netherlands. the major cause of fruit loss in strawberry (Fragaria $\mathrm{x}$ ananassa Duch.) (Rebelo \& Balardin 1997; Hancock, 1999). Flower parts play an important role in fruit infection by $B$. cinerea. Powelson (1960) and Pappas \& Jordan (1997) found that strawberry fruit infection were strongly reduced if petals, stamens, and calyces were removed after fertilisation. Detailed studies by Powelson (1960) and Bristow et al. (1986) made 
clear that infection of the stamens can result in the establishment of B. cinerea in the receptacle, whereas pistils, calyces (sepals) and petals appear not to be directly involved. The pathogen remains quiescent in the receptacle until ripening and may then cause fruit rot before or after harvest (Powelson, 1960; Jersch et al., 1989). The open flower stage was shown to be the most susceptible to the establishment of latent infections (Jarvis \& Borecka, 1968; Pappas \& Jordan, 1997). Nowadays, the conventional method of grey mould control is by a series of fungicide applications during the flowering period (Wilcox \& Seem, 1994; Maas, 1998).

Apart from their role in the establishment of latent infections, flower parts of strawberry can also be a source of inoculum for direct infection of fruits. Wilkinson (1954) and Jarvis (1962) observed that fruit infections frequently started from dead petals adhering to the surface of the fruits, or trapped between the fruit and the calyx. While the role of latent infections established during flowering has received considerable attention, no detailed studies have been conducted thus far on the importance of petals in development of grey mould in strawberry. The contribution of petals to fruit infection will depend on their susceptibility to $B$. cinerea, and on their fate after flowering. Most petals start to detach soon after fertilisation, unlike stamens and pistils that remain attached to the fruit. The reports by Wilkinson (1954) and Jarvis (1962) are rather anecdotal, and do not provide sufficient ground to determine whether control measures should be targeted at petals to eliminate this potential inoculum source, and if so, what the best timing of these control measures would be. In view of these questions, the research reported here aimed to assess the relative importance of petals as an inoculum source of grey mould in strawberry, and to identify during which period of flower and fruit development the presence of petals has a significant effect on development of grey mould. The specific objectives were (1) to understand the distribution of $B$. cinerea among petals and other flower parts of strawberry, (2) to describe symptom development on strawberry fruit with regards to the starting point of infection, and (3) to investigate the effects of petal removal at different stages of flower and fruit development on incidence of grey mould on ripe fruit.

\section{MATERIALS AND METHODS}

\section{Incidence of Botrytis cinerea on flower parts}

The incidence of $B$. cinerea on petals, stamens, and pistils was assessed in an annual crop of strawberry cv. Elsanta, near Wageningen, the Netherlands. Samples were taken from four untreated plots and from four plots where crop debris, except flower parts, were removed twice weekly. The treatment plots were laid out in four randomised blocks. A sample of 20 to 30 flowers, each flower from a different arbitrarily chosen plant, was collected per plot on July 21, August 5 and 11, 1998. Only flowers with petals and brown anthers were sampled. The flowers from each sample were put into plastic boxes $(22 \mathrm{~cm}$ length $\mathrm{x} 14 \mathrm{~cm}$ width $\times 5 \mathrm{~cm}$ height) with wet filter paper at the bottom and incubated at $18{ }^{\circ} \mathrm{C}$ for 12 days in the dark. Petals, stamens, and pistils were examined for the presence of sporulation of $B$. cinerea with a stereomicroscope at 10-100 X magnification. Flower parts were considered colonised by $B$. cinerea when at least one conidiophore was present. Flowers were classified according to the presence of $B$. cinerea sporulation on the different flower parts. Seven classes were distinguished: flowers with presence of $B$. cinerea sporulation at the same time on petals, stamens and pistils (pet_sta_pis), on petals and stamens (pet_sta), only on petals (pet), only on stamens (sta), on stamens and pistils (sta_pis), on petals and pistils (pet_pis) or only on pistils (pis). The frequency of each class, per sampling time, was expressed as a percentage of the total number of flowers with $B$. cinerea sporulation.

\section{Characterisation of grey mould symptoms on strawberry fruits}

Symptom initiation of grey mould was determined on all fruits harvested from an untreated field of strawberry cv. Elsanta near Wageningen, the Netherlands, on August 15, 20, 24, 27, and 30, 1998. Fruits with grey mould were classified by characterising the type and starting point of symptoms as follows: (a) underneath sepals with petals present (undersep_withpet); (b) underneath sepals without petals present (undersep_nopet); (c) at the middle or tip of fruits (free_surf); (d) touching infected fruits (fruit_touch); (e) soil contamination (soil_touch); (f) mummified fruits (mummy); (g) overall sporulation and unclear starting point (unclear); (h) physical surface damage (damage) and (i) pedicel grey mould (stem_rot). The frequency of each specific symptom was expressed as a percentage of the total number of fruits with grey mould, per harvest date.

\section{Petal manipulation experiments}

Experimental design, treatments and crop management. Four experiments were carried out in small field plots of strawberry cv. Elsanta, on a sandy soil near Wageningen, the Netherlands, in 1999. Cold-stored transplants kept at $-2{ }^{\circ} \mathrm{C}$ until the day before planting, were transplanted on May 6 (Exp. 1 and 2) and June 19 (Exp. 3 and 4). Each experiment consisted of 84 plants in a field plot of $4.5 \times 4.7 \mathrm{~m}$, comprising three double-rows with three plants per meter row length. Spacing between double rows was $1 \mathrm{~m}$ and within double rows 0.5 $\mathrm{m}$. Experiments 1 and 3 were conducted under natural inoculum and experiments 2 and 4 under enhanced inoculum pressure of B. cinerea. Enhanced inoculum pressure of $B$. cinerea was achieved by placing infected strawberries inside the plots, from first white bud appearance until ripening. The infected fruits, about two per plant, were deposited in rows twice per week, in the middle of double rows and at the plot margins at $30 \mathrm{~cm}$ distance from the strawberry plants. The distance between the fruits at first introduction was 15 $\mathrm{cm}$ and additional fruits were placed in between the previous ones, without removing any old fruits. Experiments of natural and enhanced $B$. cinerea inoculum pressure were separated 
by $100 \mathrm{~m}$ wide buffer strips of grass.

Treatments were as follows: petals were removed with the help of forceps at young flower (YouFlo), old flower (OldFlo) or at green fruit (GreFru) stage; all petals had dropped naturally during flowering (FreeFall) or at least one petal remained attached to the fruit till harvest (Harv); control flowers were not manipulated nor selected for presence or absence of petals (Control). All treatments were replicated three times, with the replicates grouped in double rows as blocks. Per treatment, 40-60 suitable flowers or fruits (Harv treatment) were arbitrarily chosen in each block and individually labelled by attaching a tiny label at the pedicel.

Mist irrigation was used to ensure water supply for plant development during dry periods. During flowering, irrigation was applied every second night from 21:00 till 6:00 $\mathrm{h}$ ( $5 \mathrm{~min}$ per $90 \mathrm{~min}$ period of time) to stimulate $B$. cinerea sporulation and infection. Pesticides were not applied and weeding was done manually.

Spore load in the air. Spore load in the air was monitored using Rotorod samplers Mod. 20 (Sampling Technologies, Minnetonka, USA) with a non-retracting collector. Rotorods were positioned at $0.3 \mathrm{~m}$ height in the centre of the strawberry plots, and $50 \mathrm{~m}$ outside the strawberry crops in the grass buffer. Runs were carried out on six days (May 30 and June 2, 8, 10, 15 , and 16, 1999) in experiments 1 and 2 and on seven days (June 18, 23, and 25 and July 04, 07, 15, and 22, 1999), in experiments 3 and 4. Two runs per day, except on June 18, 1999 (one run), with 15 min duration per run were carried out between 9:00 and 12:00 h, which is the most likely period for spore release of $B$. cinerea (Jarvis, 1980). The spores of one rod per run were stained with cotton blue $(2 \mathrm{ml}$ lactic acid $+4 \mathrm{ml}$ glycerol $+1.5 \mathrm{ml}$ cotton blue at $1 \%+2 \mathrm{ml}$ distilled water) and conidia of $B$. cinerea were counted on the $22 \mathrm{~mm}$ upper part of a rod using a microscope at $200 \mathrm{x}$ magnification. The number of conidia of $B$. cinerea per cubic meter of air was calculated per run and as anerage per sampling day.

Flower and fruit phenology. Labelled flowers of the first and second branches of four (Exp. 1) and three (Exp. 3) arbitrarily selected plants were monitored daily until fruit harvest. The number of petals per labelled flower from white bud appearance until harvesting was counted. These petals were either still attached to the receptacle or trapped between the sepals and the fruit. Development stages of flowers and fruits were classified as white bud (top of petals visible), open flower (fully reflexed petals until petal fall), green fruit (achene formation), fruit expansion (white fruits until fully red colour appearance) and fruit ripening (red colour appearance until fully red fruit).

Potential sporulation of $\boldsymbol{B}$. cinerea on petal. Removed petals, one per flower, of young flower (YouFlo), old flowers (OldFlo) and green fruit (GreFru) treatments in all experiments were placed on water agar $(1.5 \%$ of agar) in sterile plastic petri dishes $(\varnothing 14 \mathrm{~cm})$ and incubated for 14 days, at $18{ }^{\circ} \mathrm{C}$ in the dark. The percentage area with sporulation of $B$. cinerea was estimated for each petal using a stereomicroscope at $20 \mathrm{x}$ magnification and expressed as potential sporulation of B.cinerea on petals. Data were averaged per replicate per treatment.

Grey mould. Ripe, symptomless fruits and diseased fruits were picked twice per week. Healthy fruits were always picked separately from diseased fruits to avoid contamination during harvesting in view of post-harvest evaluations. Healthy and diseased fruits with non-specific symptoms were individually put into square plastic pots $(5 \mathrm{~cm}$ high) and pots from the same block were placed side by side into plastic trays $(50 \mathrm{~cm}$ length $\mathrm{x} 30 \mathrm{~cm}$ width $\mathrm{x} 7 \mathrm{~cm}$ height) with wet filter paper on the bottom. Each tray was sealed within a plastic bag and incubated $72 \mathrm{~h}$ at $18{ }^{\circ} \mathrm{C}$ in the dark, to allow development of specific symptoms. After incubation, fruits were checked for the presence of $B$. cinerea sporulation. Incidence of grey mould was expressed as a percentage of the total of symptomless and diseased fruits, per treatment.

\section{Data analysis}

Statistical analysis of grey mould incidence was performed by analysis of variance (ANOVA) followed by LSD-tests of angular-transformed values to separate treatment means (Snedecor \& Cochran, 1989) using the computer package Genstat 5 version 4.1 (Genstat Committee, Algorithm Group Inc.). The minimal level of significance was taken as $\mathrm{P}=0.05$. Confidence intervals were calculated for the proportion of days with a higher air load of conidia of $B$. cinerea inside the strawberry field than outside the field. The frequency of strawberry fruits over grey mould symptom categories and the frequency of $B$. cinerea over different flower parts were analysed using contingency tables and the Chi-square test. Pearson's ( $r$ ) coefficient of correlation was calculated between the incidence of grey mould in the control and the potential sporulation area of $B$. cinerea on petals sampled at young flower, old flower, and green fruit treatment stages.

\section{RESULTS}

\section{Incidence of Botrytis cinerea on flower parts}

The frequency distribution of $B$. cinerea presence on the different senescent flower parts was not significantly different over different flower parts between untreated and sanitation plots and also the distribution of this frequency was not significantly different among sampling dates within treatments (Figure 1). Petals and stamens alone or in combination, were responsible for $60-80 \%$ of $B$. cinerea incidence on flowers. Incidence of flowers with sporulation of $B$. cinerea on stamens alone or in combination with other flower parts (85-100\%) was higher than on petals alone or in combination $(65-85 \%)$, whereas this incidence on petals was higher than on pistils (20-40\%). Of all possible combinations of flower parts infected, B. cinerea never occurred on the combination petal plus pistil, without 
occurring on stamens as well.

\section{Symptom initiation of grey mould on strawberry fruits}

The distribution of strawberry fruits over grey mould symptom categories was significantly different among harvest dates $\left(\chi^{2}=148.6, \mathrm{df}=32, \mathrm{P}<0.05\right)$. The category 'touching infected fruits' and the category 'under sepal without the presence of petals' contributed most to this difference. The percentage of 'touching infected fruit' category was relatively high at the first harvest, whereas the category 'under sepals without petals' was high at the last harvest.

In $65-85 \%$ of the red strawberry fruits with grey mould, the starting point from where the symptoms had spread was located underneath the sepals (Figure 2). About half of the fruits on which grey mould had started underneath the sepals had at least one petal trapped in between sepals and fruit. Petals were associated with $20-40 \%$ of all fruit rot. Grey mould rarely started at the middle or on the tip of the fruit in absence of visible damage (1.7-8.7\%). Incidence of stem rot symptoms was low (4-6\%) and these symptoms were only observed at the end of the harvesting period.

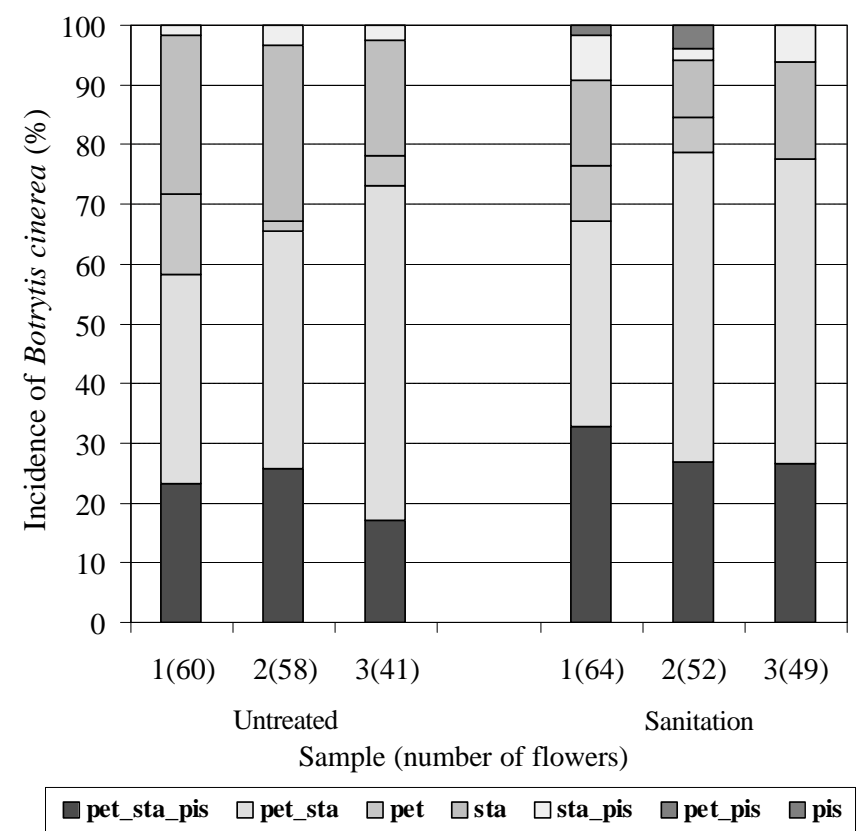

FIG. 1 - Incidence of Botrytis cinerea on senescent parts of strawberry (Fragaria $x$ ananassa) flowers sampled on Jul 21 (1), Aug 5 (2) and Aug 11 (3) 1998 from untreated plots (Untreated) and plots where all crop debris were removed, except flower parts (Sanitation). Each column shows the proportion of flowers on which $B$. cinerea was present at the same time on petals, stamens and pistils (pet_sta_pis), petals and stamens (pet_sta), only petals (pet), only stamens (sta), stamens and pistils (sta_pis), petals and pistils (pet_pis) or only on pistils (pis). Between brackets: number of flowers with $B$. cinerea sporulation per sample.
Petal manipulation experiments

Flower and fruit phenology. Petals dropped mostly during the open flower stages (Figure 3). The retention of petals from the green fruit stage until harvesting was stable with on average of 0.3 petals per flower. The frequency of flowers with a minimum of one petal followed the same trend as the number of petals per flower. During flowering (about six days), $80 \%$ of all flowers dropped all petals and the remaining $20 \%$ retained at least one petal until harvest (20 days).

Spore load in the air. The number of conidia per $\mathrm{m}^{3}$ of air was always higher inside field plots with enhanced inoculum pressure of $B$. cinerea $\left(>100 \mathrm{~m}^{-3}\right)$ than inside field plots with natural inoculum pressure $\left(12-16 \mathrm{~m}^{-3}\right)$ or outside the strawberry plots (10-14 $\mathrm{m}^{-3}$ ) (Table 1$)$. A higher conidial load of $B$. cinerea inside the plot with natural inoculum pressure as compared to outside the plot was found on four of six days in experiment 1 , and on four of seven days in experiment 3. The proportion of days on which more conidia were found inside the plot with natural inoculum than outside the plot was not statistically different from 0.5 , which is the expected

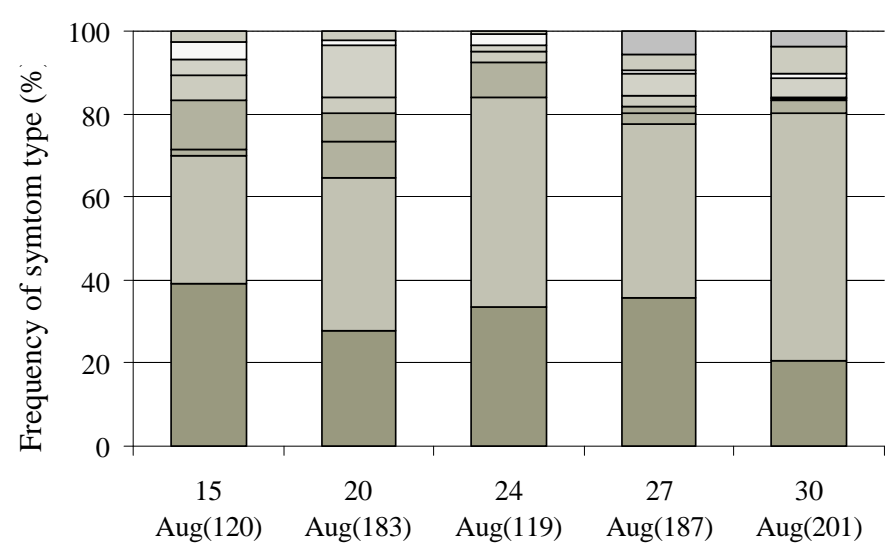

Harvest (total number of fruits)

\begin{tabular}{|c|c|c|}
\hline \multicolumn{2}{|c|}{$\square$ undersep_withpet $\square$ undersep_nopet } & $\square$ free_surf \\
\hline$\square$ fruit_touch & $\square$ soil_touch & $\square$ mummy \\
\hline$\square$ unclear & $\square$ damage & $\square$ stem_rot \\
\hline
\end{tabular}

FIG. 2 - Frequency of type and starting point of grey mould symptoms caused by Botrytis cinerea on strawberry (Fragaria $x$ ananassa) fruits from untreated plants evaluated on August 15, 20, 24, 27, and 30, 1998. Symptoms were classified according to type and starting point as follows: under sepals with presence of petals (undersep_withpet) or without petals (undersep_nopet); at middle or tip of fruits (free_surf); touching infected fruits (fruit_touch); soil contamination (soil_touch); mummified fruits (mummy); generalised sporulation and starting position (unclear); surface physical damage (damage) or pedicel grey mould (stem_rot). 
TABLE 1 - Air load of conidia of Botrytis cinerea sampled by Rotorods during flowering of strawberry (Fragaria $\mathbf{x}$ ananassa)

\begin{tabular}{|c|c|c|c|c|c|c|}
\hline \multirow[b]{2}{*}{ Experiment } & \multicolumn{3}{|c|}{ Number of conidia per $\mathrm{m}^{3}$ of air per run } & \multicolumn{3}{|c|}{ Proportion of days with air load inside field plot with } \\
\hline & $\begin{array}{l}\text { Inside field plot } \\
\text { with enhanced } \\
\text { inoculum } \\
\text { pressure }\end{array}$ & $\begin{array}{l}\text { Inside field plot } \\
\text { of natural } \\
\text { inoculum } \\
\text { pressure }\end{array}$ & $\begin{array}{c}\text { Outside } \\
\text { field } \\
\text { plots }^{b}\end{array}$ & $\begin{array}{c}\text { Enhanced } \\
\text { inoculum }> \\
\text { Natural } \\
\text { inoculum }\end{array}$ & $\begin{array}{c}\text { Enhanced } \\
\text { inoculum }> \\
\text { Outside field } \\
\text { plots }\end{array}$ & $\begin{array}{c}\text { Natural } \\
\text { inoculum }> \\
\text { Outside field } \\
\text { plots }\end{array}$ \\
\hline 1,2 & 101 & 16 & 10 & 1.0 & 1.0 & $0.67^{\mathrm{c}}$ \\
\hline 3,4 & 129 & 12 & 14 & 1.0 & 1.0 & $0.57^{\mathrm{d}}$ \\
\hline
\end{tabular}

${ }^{a}$ Rotorods run on six days in experiments 1 and 2, and on seven days in experiments 3 and 4

${ }^{\mathrm{b}}$ Rotorods were located $50 \mathrm{~m}$ from field plots.

c $95 \%$ confidence interval: $(0.33,0.91)$

d $95 \%$ confidence interval: $(0.24,0.87)$

value when spore loads do not differ (Table 1,95\% confidence intervals).

Potential sporulation of $B$. cinerea on petals. The potential sporulation area of $B$. cinerea was higher on petals from experiments 2 and 4 with an enhanced inoculum pressure than from experiments 1 and 3 with natural inoculum pressure (Figure 4). In general, the potential sporulation area of $B$. cinerea increased with exposure time of petals to the inoculum present in the field. Petals sampled at green fruit stage always had a larger potential sporulation area of $B$. cinerea than those sampled at young flower stages.
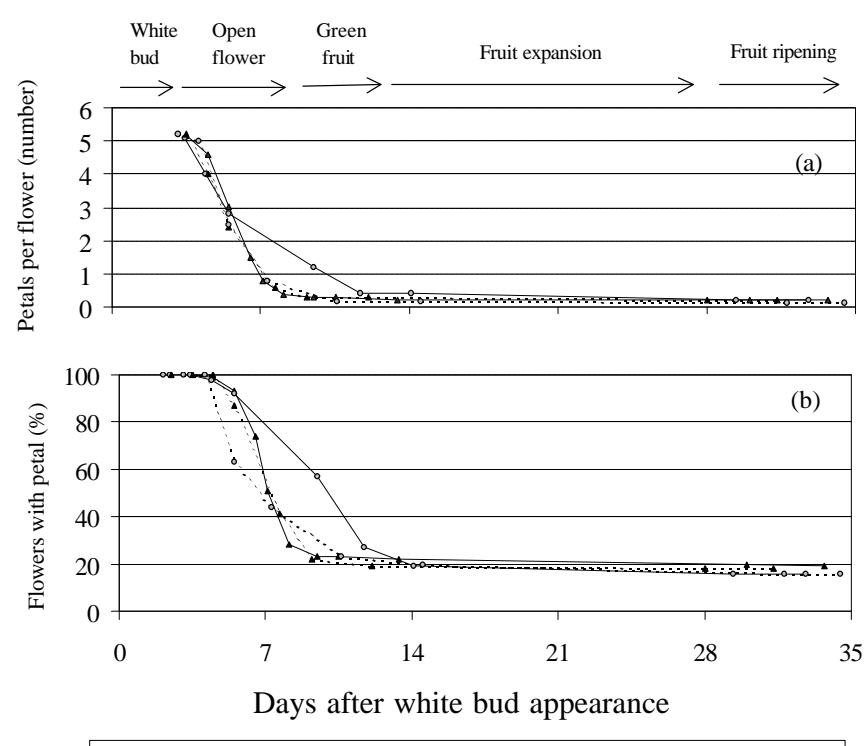

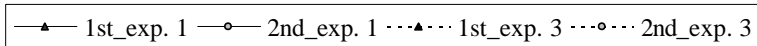

FIG. 3 - Petal retention of cv. Elsanta from white bud appearance till harvest. (a) number of petals present per flower and (b) percentage of flowers with at least one petal per flower. Data from flowers of first (1st_exp. 1, 69 flowers) or second (2nd_exp. 1, 38 flowers) branch of experiment 1, on Apr 16, 1999 and from first (1st_exp. 3, 51 flowers) or second (2nd_exp. 3, 43 flowers) branch of experiment May 3, on 11, 1999.
Grey mould. In all experiments fruits with grey mould were found, but the incidence was considerably higher in experiment 2 and 4 with the enhanced inoculum pressure (Figure 5). Incidence of grey mould on fruits in the untreated control was 5-15\% under natural inoculum pressure, and 25$55 \%$ under enhanced inoculum pressure of $B$. cinerea. Between experiments, the incidence of grey mould in the control was positively correlated $(\mathrm{df}=2, \mathrm{P}<0.05)$ with the potential sporulation area of $B$. cinerea on petals sampled at young flower $(\mathrm{r}=0.99)$, old flower $(\mathrm{r}=0.95)$, and green fruit stage $(r=0.98)$. When petals were present until harvest, significantly more grey mould occurred in comparison to all other treatments, irrespective the inoculum pressure of $B$. cinerea or the planting date (Figure 5). For example, the difference in grey mould incidence between the treatments with petals present until harvest and with petals naturally dropped during flowering, was $51 \%, 51 \%, 54 \%$ and $66 \%$ in experiment $1,2,3$, and 4 , respectively. Incidence of grey mould on fruits with petals retained until harvest was higher

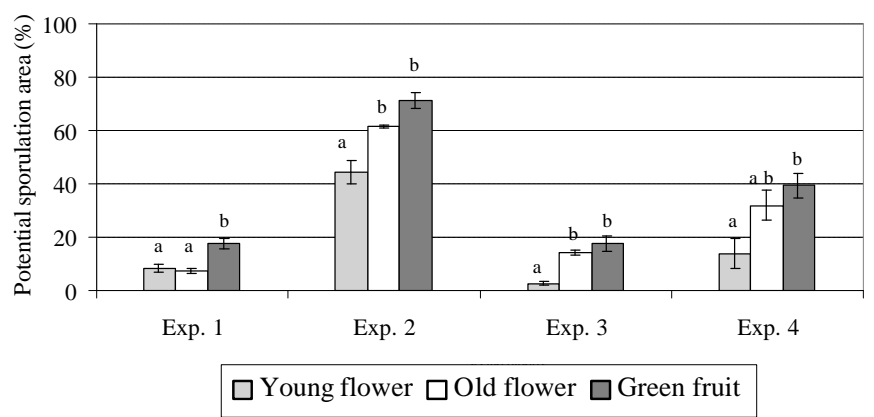

FIG. 4 - Potential sporulation area of Botrytis cinerea on petals sampled from strawberry (Fragaria $\mathbf{x}$ ananassa) crops under natural inoculum pressure (exp. 1 and 3) and enhanced inoculum pressure (exp. 2 and 4) of the pathogen. Petals sampled at young flower, old flower or green fruit stage were incubated in moist chamber at $18{ }^{\circ} \mathrm{C}$ for 14 days, in the dark. Columns with the same letter in the same experiment are not significantly different (LSD-test; $\mathbf{P}=\mathbf{0 . 0 5}$ ). Bars represent standard error of means of three replicates. 
The role of petals in development of grey mould in strawberries
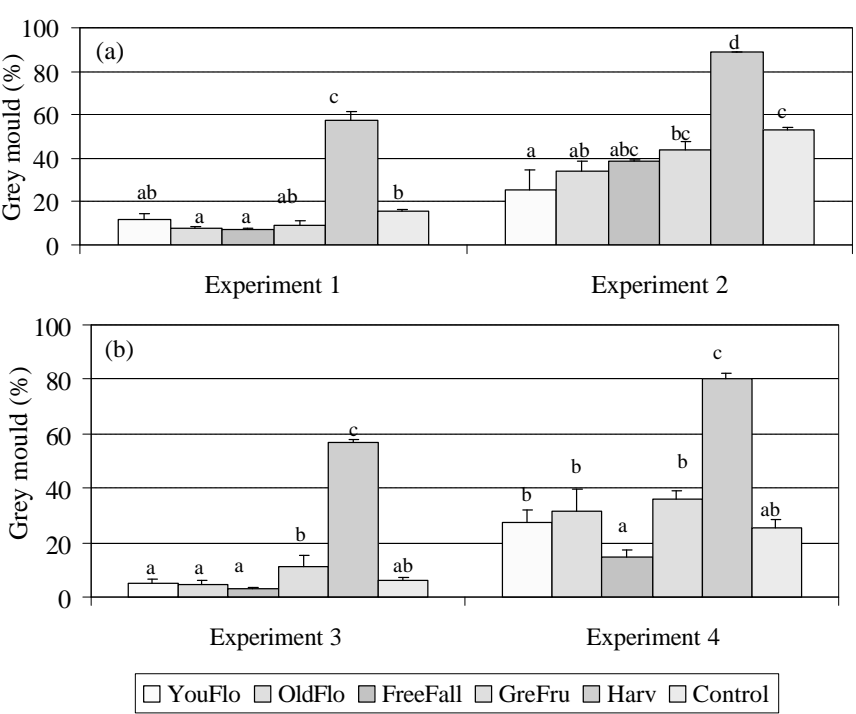

FIG. 5 - Incidence of grey mould of strawberry (Fragaria $x$ ananassa) under natural (exp. 1 and 3) and enhanced (exp. 2 and 4 ) inoculum pressure of Botrytis cinerea, in annual strawberry crops transplanted on April 16, 1999 (a) and on May 11, 1999 (b). Treatments were: petals removed at young open flower (YouFlo), old flower (OldFlo) or green fruit (GreFru) stages; all petals dropped naturally during flowering (FreeFall) or petals remained attached to the fruit till harvest (Harv); non-manipulated flowers (Control). Columns of the same experiment with the same letter are not significantly different (LSD-test; $P=0.05)$. Bars represent standard error of means of three replicates.

under enhanced inoculum pressure (80-90\%) than under natural inoculum pressure (55-60\%) of B. cinerea. Removal of petals either at young open flower stage, old flower stage, or at green fruit stage had no or hardly any differential effect on grey mould of fruits. Among these three treatments, incidence of grey mould was highest in the treatment where the petals had been removed at the green fruit stage in three of four experiments, but significant differences were only found in experiment 2 and 3. Incidence of grey mould was lowest on fruits that originated from flowers of which all petals had dropped naturally during flowering in three of four experiments, but did not differ significantly from the incidence in the treatments where petals had been removed at the young or old flower stage, except in experiment 4.

\section{DISCUSSION}

\section{Role of petals in strawberry grey mould}

Botrytis cinerea was found on the stamens, petals, and pistils of strawberry flowers (Figure 1). The incidence on petals was somewhat lower than on stamens, but clearly higher than on pistils. Although the different flower parts differ greatly in size and number, the difference in incidence may be related to their degree of susceptibility to colonisation by $B$. cinerea. Bristow et al. (1986) found that $B$. cinerea readily colonises anthers and internal tissues of petals, whereas $B$. cinerea could also infect pistils, but hyphal growth was very slow and restricted.

The characterisation of the type and starting point of grey mould symptoms on strawberry fruits showed that in the majority of cases the infection had started underneath the sepals (65-85\% of diseased fruits, Figure 2). These results are very similar to those obtained by Powelson (1960), who found in a survey of five strawberry fields that $71-87 \%$ of the rotting fruits were infected at the calyx end, and suggested that the rot originated from infected stamens or sepals. However, our finding that petals were present in about 50\% of the cases where grey mould symptoms had spread from underneath the sepals, indicates that petals also can play an important role in fruit infection. Sepals hardly senesce until harvest and do not appear to be directly involved in infections at the stem end of fruits (Powelson, 1960), but they may contribute indirectly by trapping petals, moisture, and conidia of $B$. cinerea. The low incidence of grey mould symptoms starting at the middle or the tip of fruits, confirms previous observations that infections of intact fruit from airborne conidia rarely occur under field conditions (Jarvis, 1962).

The experiments, in which the role of petals was investigated, demonstrated that the retention of petals until harvest greatly enhanced the incidence of grey mould (Figure 5 ). The additional percentage of grey mould that can be attributed to the presence of petals from flowering until harvest was $51-65 \%$, calculated as the difference in grey mould incidence between the treatment with petals present until harvest and the treatment in which petals had dropped naturally by the end of flowering. This percentage was remarkably constant across the experiments, which represented different levels of inoculum pressure and, because of the two transplanting times, also different weather conditions. In contrast, the degree of grey mould not associated with the presence of petals, for example in those treatments where the petals were removed during the flowering stages or where the petals had dropped naturally during flowering, was much more variable across the four experiments (Figure 5). It seems that petals adhering to the fruit surface are an effective and reliable source of fruit infection by $B$. cinerea. These petals may act as a saprophytic base for invading mycelium, or facilitate conidial infections by trapping spores and water in between the petal and the fruit surface. The latter mechanism is probably of minor importance, because the epidermis of strawberry fruit is not easily penetrated successfully by conidia of $B$. cinerea, unless the fruits are fully ripe (Jersch et al., 1989), whereas infection with mycelial plugs is more effective, even of half-ripe fruits (Jarvis \& Borecka, 1968). Kamoen et al. (1985) suggested that the saprophytic base provided by adhering senescent petals already detached at the base of the flower may function as protection for the pathogen against inhibitors from the plant, 


\section{P. Boff et al.}

and allow the fungus to grow and produce toxins or enzymes needed to overcome plant resistance. Mycelial infection from petals colonised by $B$. cinerea is also probably less dependent upon weather conditions because moisture requirements are less strict than for conidial infection. When petals are present throughout fruit development, the chance that these petals will eventually be colonised by $B$. cinerea is high even when the inoculum pressure is relatively low.

\section{When does fruit infection through the presence of petals occur?}

The presence of petals up to the green fruit stage had little or no influence on the incidence of grey mould (Figure 5 ). The period during which petals may act as a source of fruit infection by $B$. cinerea is mainly between the green fruit stage and harvest. This can be explained with the results from Powelson (1960), who concluded that petals do not play a role in the establishment of latent infections in the receptacle during flowering, because an abscission layer causes the petals to fall before the fruit is invaded. Regarding mycelial or conidial infection of intact fruit, several studies have shown that intact young, green fruits are highly resistant to $B$. cinerea, whereas the susceptibility of the fruits increases towards maturity (Jarvis \& Borecka, 1968; Jersch et al., 1989). In addition to the greater susceptibility of ripening fruit, the effect of petal retention until harvest can be explained by the long exposure time of the petals to Botrytis inoculum resulting in higher levels of petal colonisation (Figure 4). The long period of contact between the petals and fruits also enhances the probability of an infection event.

\section{Implications for control}

Whereas the retention of petals after the green fruit stage enhances the probability of fruit infection considerably, the need to eliminate this inoculum source will depend on how frequent petal retention is during fruit expansion and ripening. We observed that in strawberry cv. Elsanta at least one petal was retained on about $20 \%$ of all fruits (Figure 3 ). This is relatively low and may explain why the role of petals has not been studied in detail, in contrast to the role of permanent flower parts (stamens, pistils, and sepals). The reduction in grey mould achieved by elimination of petals, as compared to non-intervention (untreated control), appears rather limited in our study. Only in the first two experiments significant differences were found between the incidence of grey mould in the control and in any of the treatments where petals had been removed or dropped naturally during flowering (Figure 5). However, it can be argued that the observed level of reduction in grey mould incidence was in agreement with the expected level. Given that in the control treatment petals were present on $20 \%$ of the fruits, and that the presence of petals from flowering until harvest on all fruits enhances the incidence of grey mould by about $50 \%$, an additional $10 \%$ grey mould would be expected in the control treatment as compared to treatments where petals were absent from the end of flowering onwards. The observed difference between these treatments and the control was on average $7.5 \%$. Thus, considering the high probability that presence of a petal results in fruit infection, the elimination of petals as an inoculum source appears worthwhile even when the incidence of petal retention on fruit is relatively low.

Elimination of petals as an inoculum source of strawberry grey mould may be achieved by specific measures such as selection of cultivars that drop (almost) all petals or by physical removal of petals by blowing with compressed air. The latter approach has some success in viticulture, where it is used to remove flower caps from the grape (Vitis vinifera L.) clusters (Wolf et al., 1997), but may be problematic in strawberry where the flowering period is long with overlapping generations of flowers. The conventional way to control grey mould is by application of fungicides during flowering (Maas, 1998). These spray applications also blow off petals, which may additionally contribute to grey mould control. Fungicides will reduce colonisation of petals most effectively when applied protectively, i.e. before the arrival of inoculum of $B$. cinerea, because their post-infection effect on petals is poor (Kamoen \& Jamart, 1975). The best timing of fungicide applications to control this source of inoculum will therefore probably be during flowering, although the petals give rise to fruit infections much later during fruit development. Colonisation of petals by $B$. cinerea may also be prevented or reduced by saprophytic competitors such as Gliocladium roseum (Bainier) and Ulocladium atrum (Preuss) (Peng \& Sutton, 1991; Köhl et al., 1995). For these biocontrol agents, timing of application may also be critical, because the time advantage of one species over the other plays a crucial role in competitive colonisation of substrates by B. cinerea and the antagonist (Kessel, 1999). Yet, such biocontrol agents are promising means to protect petals against $B$. cinerea, because once successfully established they may be able to exclude $B$. cinerea for the rest of the growing season whereas a fungicide application offers protection for only a limited period.

\section{ACKNOWLEDGEMENTS}

Funding for this research was partly provided by the Brazilian Government - Coordenação de Aperfeiçoamento de Pessoal de Nível Superior (CAPES; Proc. 2959/95-0), which included a full scholarship to the first author. We also acknowledge the European Commission (BIOSPORSUPPRESS; FAIR3 CT96-1898) for partial financial support for the research. We thank Saskia Burgers for statistical assistance.

\section{LITERATURE CITED}

BRISTOW, P.R., MCNICOL, R.J. \& WILLIAMSON, B. Infection of strawberry flowers by Botrytis cinerea and its relevance to grey mould development. Annals of Applied Biology 109:545-554. 1986.

HANCOCK, J.F. STRAWBERRIES. Wallingford, UK. CABI Publishing. 1999.

JARVIS, W.R. The infection of strawberry and raspberry fruits by 
Botrytis cinerea Fr. Annals of Applied Biology 50:569-575. 1962. JARVIS, W. R. Epidemiology. In: Coley-Smith, J.R., Verhoeff, K.\& Jarvis, W. R. (Eds.) The Biology of Botrytis. London, UK. Academic Press. 1980. pp.219-250.

JARVIS, W.R. \& BORECKA, H. The susceptibility of strawberry flowers to infection by Botrytis cinerea Pers. ex Fr. Horticulture Research 8:147-154. 1968.

JERSCH, S., SCHERER, C., HUTH, G. \& SCHLÖSSER, E. Proanthocyanidins as basis for quiescence of Botrytis cinerea in immature strawberry fruits. Journal of Plant Diseases and Protection 96:365-378. 1989.

KAMOEN, O., JAMART, G., VAN VAERENBERGH, J. \& GOUWY, P. Botrytis cinerea infections on petals and green leaves. Mededelingen van de Faculteit Landbouwwetenschappen Rijksuniversiteit Gent 50/3b:1053-1058. 1985.

KAMOEN, O. \& JAMART, G. Further examination of the strawberry fruit rot control by fungicides. Acta Botanica Neerlandica 24:253254. 1975.

KESSEL, G.J.T. Biological control of Botrytis spp. by Ulocladium atrum, an ecological analysis. (PhD thesis). Wageningen, NL. Wageningen University. 1999.

KÖHL, J., MOLHOEK, W.M.L., VAN DER PLAS, C.H. \& FOKKEMA, N.J. Effect of Ulocladium atrum and other antagonists on sporulation of Botrytis cinerea on dead lily leaves exposed to field conditions. Phytopathology 85: 393-401. 1995.
MAAS, J.L. Compendium of strawberry diseases. $2^{\text {nd }}$ ed. St. Paul, USA. American Phytopathology Society. 1998.

PAPPAS, A.C. \& JORDAN, V.W.L. Phenology of fruit growth and susceptibility to grey mould (Botrytis cinerea) of strawberry, raspberry and blackcurrant. Annals Institute Phytopathology Benaki 18:1-11. 1997

PENG, G. \& SUTTON, J.C. Evaluation of microorganisms for biocontrol of Botrytis cinerea in strawberry. Canadian Journal of Plant Pathology 13:247-257. 1991.

POWELSON, R.L. Initiation of strawberry fruit rot caused by Botrytis cinerea. Phytopathology 50:491-494.1960.

REBELO, J.A. \& BALARDIN, R.S. A cultura do morangueiro. Florianópolis, BR. Epagri. 1997.

SNEDECOR, G.W. \& COCHRAN, W.G. Statistical methods. $8^{\text {th }}$ ed. Iowa, USA. Iowa State University Press. 1989.

WILCOX, W.R. \& SEEM, R.C. Relationship between strawberry gray mold incidence, environmental variables, and fungicide applications during different periods of the fruiting season. Phytopathology 84:264-270. 1994.

WILKINSON, E.H. Observations on grey mould in strawberries. Plant Pathology 3:12. 1954.

WOLF, T.K., BAUDOIN, A.B.A.M. \& MARTINEZ-OCHOA, N. Effect of floral debris removal from fruit clusters on botrytis bunch rot of Chardonnay grapes. Vitis 36:27-33. 1997. 